\title{
The role of infochemicals in the interaction between cassava green mite and its fungal pathogen Neozygites tanajoae
}

\author{
F.C.C. Hountondji1,2,3, M.W. Sabelis² \& R. Hanna1 \\ 1 International Institute of Tropical Agriculture, 08 BP 0932, Cotonou, Republic of Benin, 2Institute for Biodiversity and \\ Ecosystem Dynamics, Population Biology Section, University of Amsterdam, 94084, 1090 GB Amsterdam, The Netherlands, \\ and 3Expertise, Action and Research for Development (EAR-Development), PO Box 2015 Abomey-Calavi, Republic of Benin. \\ E-mail: fabienho@yahoo.com
}

\begin{abstract}
The role of infochemicals in mediating interactions between herbivores and their foraging natural enemies, mainly predators and parasitoids, is well established, but very little is known about infochemical use in interactions between herbivores and their sit-and-wait pathogens. This paper reviews the role of infochemicals in interactions between the cassava green mite (CGM), Mononychellus tanajoa, and its fungal pathogen, Neozygites tanajoae. In a closed-dish test, herbivore-induced plant volatiles (HIPV) from cassava were found to influence conidia and capilliconida production of the fungus but the effect of HIPV varied between isolates. HIPV consistently promoted conidia production of one isolate and capilliconidia production of another. Olfactory trials with one of the HIPV, methyl salicylate (MeSA), also promoted conidia production of the same isolate, but no effect was found on capilliconidia production. In contrast to the effect of HIPV, green leaf volatiles inhibited spore production, suggesting that the fungus uses HIPV to signal the presence of hosts. The behaviour of the mite towards infective spores was investigated in a two-choice unit (discs with vs. without spores) and on detached leaves. Mites avoided the discs with spores, in particular for one isolate. Similar observations were made on detached leaves where more mites were found on leaf lobes without spores than on those with spores. However, mites did not avoid mummified infected mites that did not yet produce spores, suggesting that the fungus may profit from going unnoticed inside the live infected mite to reach densely infested patches.
\end{abstract}

Key words: Acaropathogen, avoidance, green leaf volatiles, herbivore-induced plant volatiles, methyl salycilate, Mononychellus tanajoa

$\mathrm{M}$ uch evidence has been established regarding the role of infochemicals in mediating interactions between herbivores and their predators or parasitoids. These interactions can be mediated by volatiles emitted by the host plant as well as by cues produced by the herbivore and its natural enemies. Since the suggestion by Price et al. (1980) that plants can influence the third trophic level, many studies have been conducted on interactions within trophic systems involving predators and parasitoids in the laboratory and in the greenhouse. These studies have shown that herbivoreinduced plant volatiles (HIPV) play a role in the attraction of predators and parasitoids to plants under attack by herbivores (Dicke \& Sabelis, 1988; Dicke et al., 1990; Turlings et al., 1990; Gnanvossou et al., 2001; James, 2005).

Apart from volatiles emitted by plants, cues released by herbivores or their natural enemies may also influence the behaviour of the natural enemy or the herbivorous victim. Evidence has been established where prey and host hide and escape from their predators and parasitoids (e.g., Janssen et al., 1998; Pallini et al., 1999; Magalhães et al., 2002; Grostal \& Dicke, 2000). It is also evidenced that predators or parasitoids can be influenced by cues of their prey/host or by their conspecific or heterospecifics (Janssen et al., 1997, 1998; Outreman et al. 2001; Nakeshima et al., 2004)

Although the use of infochemicals is well established for predators and parasitoids, very little is known about the use of infochemicals by arthropod pathogens, particularly fungi. Earlier reports include the observation of avoidance of Beauveria bassiana-infected conspecifics by the ant Solenopsis invicta (see review by Oi and Perera, 1993) and studies by Brown et al. (1995) on the aphid pathogen Pandora neoaphidis and Klingen et al. (2002) on the common arthropod pathogens Metarhizium anisopliae and Tolypocladium cylindrosporium. Brown et al. (1995) reported delay in germination of conidia of $P$. neoaphidis until after the pathogen comes into contact with its aphid host, whereas Klingen et al. (2002) reported an in-vitro inhibitory effect of isothyocyanates on $M$. anisopliae and T. cylindrosporium. Only recently, specific studies on the effect of HIPV on entomopathogenic fungi have been conducted with the entomophthorales Neozygites tanajoae (Hountondji et al., 2005) and P. Neoaphidis (Baverstock et al., 2005). Moreover, a series of interactions studies have been conducted on the $N$. tanajoae system which involves the cassava green mite (CGM), Mononychellus tanajoa (Bondar), a pest of cassava.

Neozygites tanajoae is pathogenic to CGM (Delalibera \& Hajek, 2004; Delalibera et al., 2004), which is a major pest of cassava, a staple food crop in Africa (Yaninek \& Herren, 1988). Neozygites tanajoae causes severe epizootics in Northeastern Brazil (Delalibera et al., 1992), whereas in Africa very low infections have been reported (Yaninek et al., 1996; Dara et al., 2001). On the cassava leaf the acaropathogenic fungus completes its cycle by attaching to mobile CGM stages by means of spores produced by sporulating infected mite cadavers. The attached spores germinate, invade the body of the mite, and cause its death within ca. 3-4 days at $28{ }^{\circ} \mathrm{C}$ (Oduor et al., 1995). Infected mites dry out and become mummified after death. These so-called mummies sporulate and spread spores over the leaf when relative humidity is near saturation and temperature around 18-23 ${ }^{\circ} \mathrm{C}$, in the dark (Oduor et al., 1996).

In this paper we present the results of studies conducted on the N. tanajoae-M. tanajoa-cassava system towards understanding the role infochemicals can play in the interactions within such a system. In particular, the effect of plant volatiles on the development of the acaropathogen and the role of cues from the acaropathogen and from the mite are investigated. 


\section{MATERIALS AND METHODS}

Two main studies were conducted from 2002-2006 to understand the role of infochemicals in mediating interactions within the $N$. tanajoae-M. tanajoa-cassava system. One study evaluated the effect of green leaf volatiles (GLV) and HIPV on the development of the acaropathogen. A second study assessed the behaviour of the herbivorous mite (avoidance) imposed by cues released by $N$. tanajoae associated or not with its host.

Two isolates of $N$. tanajoae were used in the experiments. One Brazilian isolate collected from Colas das Almas in the state of Bahia in 1995 (Colal.brz), and one Beninese isolate collected from Cotonou in 1997 (Coton.ben). The isolates were maintained at $4{ }^{\circ} \mathrm{C}$ inside tightly closed photographic film canisters on top of dry cotton wool with glycerol at the bottom to keep humidity low. The stored specimens were renewed at approximately 6-month intervals through host-to-host multiplication to minimize loss of viability.

\section{Effect of plant volatiles on Neozygites tanajoae}

In this study, the influence of cassava GLV and M. tanajoainduced cassava volatiles (HIPV) on N. tanajaoe was evaluated. As described above, $N$. tanajoae displays a sit-and-wait strategy to infect its host. Therefore, unlike predators and parasitoids that are shown to respond behaviourally to HIPV, we hypothesized that HIPV affect spore production. Two types of experiments were conducted. One experiment was carried out in a closed-dish environment in which CGM mummies infected by $N$. tanajoae were placed for sporulation, either exposed to GLV from clean, excised leaf discs, or to HIPV from excised leaf discs fed upon by CGM, or to dead $N$. tanajoae-infected mites or to clean air (control). The second experiment consisted of an airflow experiment where mummies were allowed to sporulate under HIPV environment provided by highly infested cassava leaves against clean air. For details about the design of these two experiments, see Hountondji et al. (2005).

Following a gas chromatography-mass spectrometry (GC-MS) analysis conducted to identify volatiles produced by cassava following herbivory by $M$. tanajoa, a few volatiles were identified as HIPV, including methyl salicylate (MeSA), a compound known to attract predators and parasitoids in many herbivorous arthropod-plant systems. As part of the HIPV tests, the effect of synthetic MeSA on the sporulation of $N$. tanajoae was also tested in an additional experiment. Mummified mites infected by $N$. tanajoae were allowed to sporulate in a closed plastic box in an environment with or without MeSA (Hountondji et al., 2006).

\section{Avoidance study}

To test whether CGM can avoid contact with the fungal spores, its behaviour in the presence of spores of $N$. tanajoae was assessed. In a two-choice unit female spider mites are allowed to make a choice between two opposite leaf discs, one with spores of $\mathrm{N}$. tanajoae and the other without spores. The leaf discs were placed on top of moist cotton to prevent escape of CGM, and connected by a thin wooden bridge on the middle of which were placed the test mites. After $24 \mathrm{~h}$ the position of the mites was scored. Spores were obtained by incubating mummified mites infected by $N$. tanajoae for sporulation on the leaf disc to be treated. Since mummified infected mites may not sporulate immediately after formation depending on the prevailing conditions, we also tested the behaviour of the mite towards the fungus inside the mite using the same unit.

To mimic realistic conditions, the behaviour of the mite towards spores of $N$. tanajoae was also tested on cassava leaves. The leaves were placed upside down over an arena of moist cotton pad to prevent $M$. tanajoa from escaping. Test mites were placed on top of the petiole (partially cut off to allow only ca. $3 \mathrm{~cm}$ walk to the leaf blade) from where they are allowed to choose between lobes with and without spores in alternate positions.

\section{Statistical analysis}

Analyses of variance (ANOVA) were conducted using SPSS 12.0 for Windows to analyze spore production in the closeddish experiment and to study preference of CGM between treated and control lobes of cassava leaves in the avoidance study. The Student t-test was used to compare spore production between treatment and control in the airflow trials and to analyze CGM preference between leaf discs with and without spores in the avoidance test.

\section{RESULTS}

\section{GLV and HIPV studies}

The results of the experiment conducted on leaf discs showed that odours can influence conidiation of the acaropathogen, and that the effect of these odours depends on pathogen isolate. There was a significant difference between the odour treatments for the isolate Colal.brz $\left(F_{3}=6.80, P=0.001\right)$, whereas no consistent difference was observed for the isolate Coton.ben $\left(F_{3}=0.20, P=0.89\right)$. Mean separation using Tukey's Studentized range test at the $5 \%$ level showed that conidia production by Colal.brz under clean air and environ-

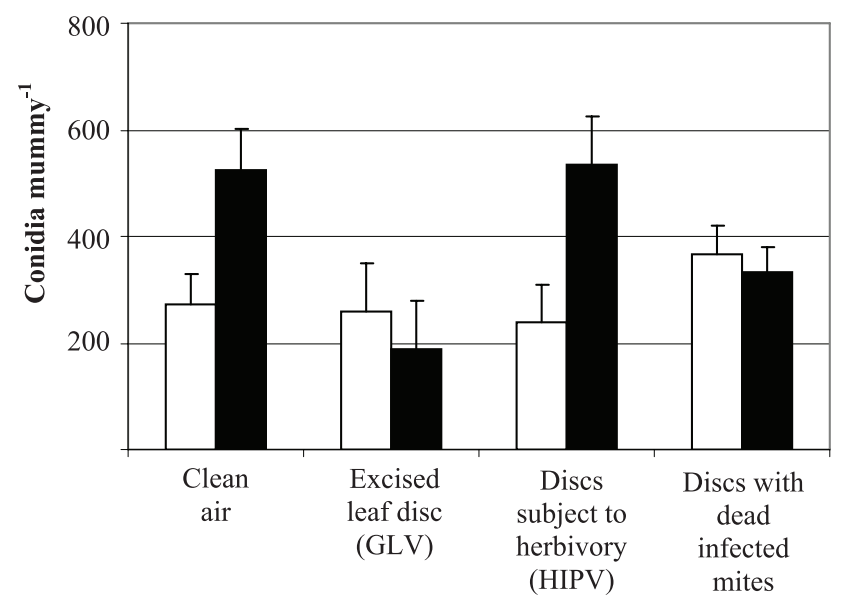

Figure 1 Conidia production of a Beninese isolate (Coton.ben; white bars) and a Brazilian isolate (Colal.brz; black bars) of Neozygites tanajoae in closed dish environment in the presence of green leaf volatiles (GLV), green mite-induced cassava volatiles and infected mites against the control (clean air). 
ment with leaf discs fed upon by CGM was higher than in an environment with odours from a clean excised leaf disc (Fig. 1). No consistent difference was found between an environment with infected CGM on the leaf discs and any of the other environments (clean air, GLV, HIPV). Also, no effect of the odours was observed on the production of capilliconidia for any of the isolates ( $P>0.05$; results not shown).

The airflow experiment, where cues from cassava leaves highly infested by CGM were compared with clean air, also demonstrated that volatiles have an effect on sporulation of $N$. tanajoae and that the effect varied with isolate (Fig. 2). For Coton.ben, in presence of HIPV more conidia were made than under clean air $(251.0 \pm 33.6$ vs. $183.8 \pm 28.7$ conidia/mummy, respectively; $\mathrm{P}=0.07$ ). No consistent difference was found for isolate Colal.brz, although more conidia were produced in presence of HIPV than in clean air $(404.7 \pm 66.2$ vs. $354.0 \pm 48.9$ conidia/mummy; $P=0.27$ ). The effect of volatiles was also seen for capilliconidia production, but only for Colal.brz. The proportion of capilliconidia formed from conidia was significantly

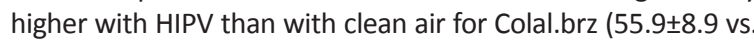
$31.9 \pm 6.9$ conidia/mummy; $P=0.02$ ), but they were similar for Coton.ben ( $58.1 \pm 8.2$ vs. $65.2 \pm 5.8$ conidia/mummy; $P=0.27$ ).

Similar findings were obtained for conidia production when MeSA was tested (Fig. 3). Higher conidia production was observed in the presence of MeSA than under clean air for Coton.ben $(265.2 \pm 43.5$ vs. $184.1 \pm 36.3$ conidia/ mummy, respectively; $P=0.08)$ and no consistent difference for Colal.brz ( $360.5 \pm 46.0$ vs. $384.6 \pm 50.2$ conidia/mummy; $P=$ $0.36)$. In contrast, no effect was observed in capilliconidia production for any of the isolates.

\section{Avoidance study}

Evidence for $M$. tanajoa avoiding the acaropathogen was obtained but this depended on the pathogen state and the
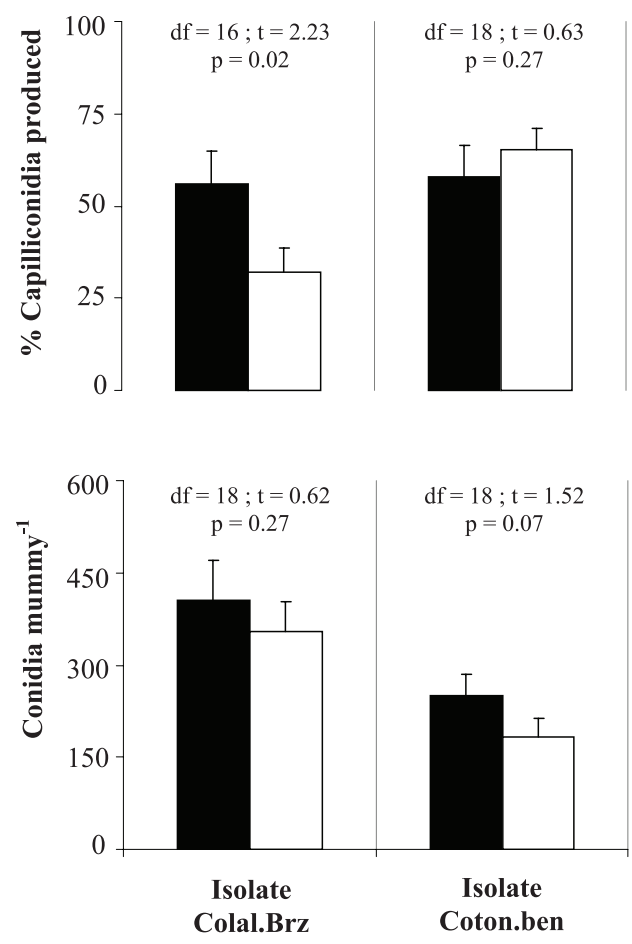

Figure 2 Conidia production and capilliconidia production of a Beninese isolate (Coton.ben) and a Brazilian isolate (Colal.brz) of Neozygites tanajoae in a two-arm airflow experiment with cassava leaves infested by the green mite Mononychellus tanajoa one side (black bars) and clean air the other side (white bars). isolate (Fig. 4). When the pathogen was outside the mite as spores, avoidance was observed for both isolates, with a stronger avoidance for the Colal.brz isolate $(P=0.009)$ compared with the Coton.ben isolate $(P=0.09)$. Fewer mites
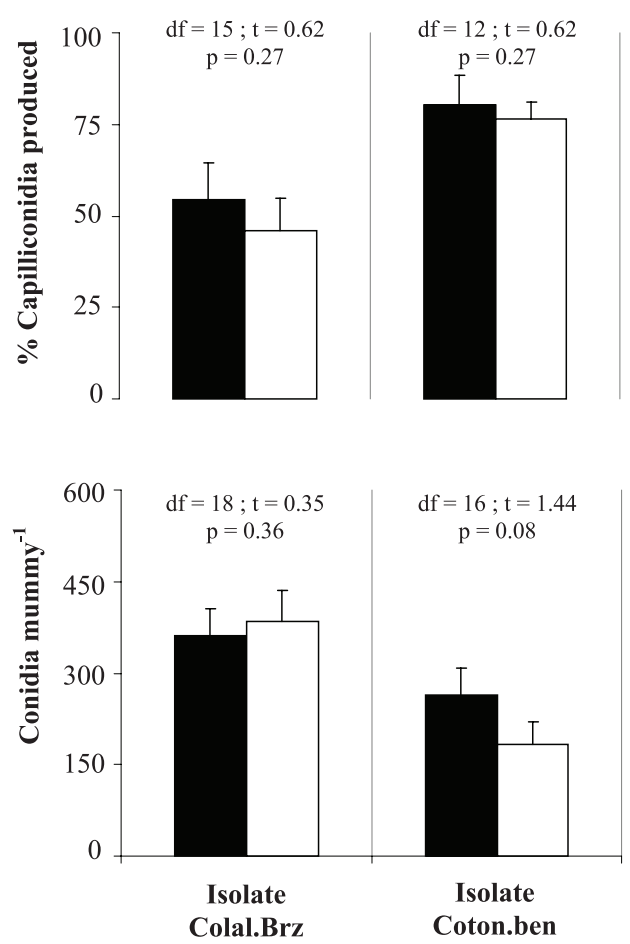

Figure 3 Conidia and capilliconidia production of a Beninese isolate (Coton.ben) and a Brazilian isolate (Colal.brz) of Neozygites tanajoae in an environment with (black bars) and without methyl salycilate (MeSA; white bars).
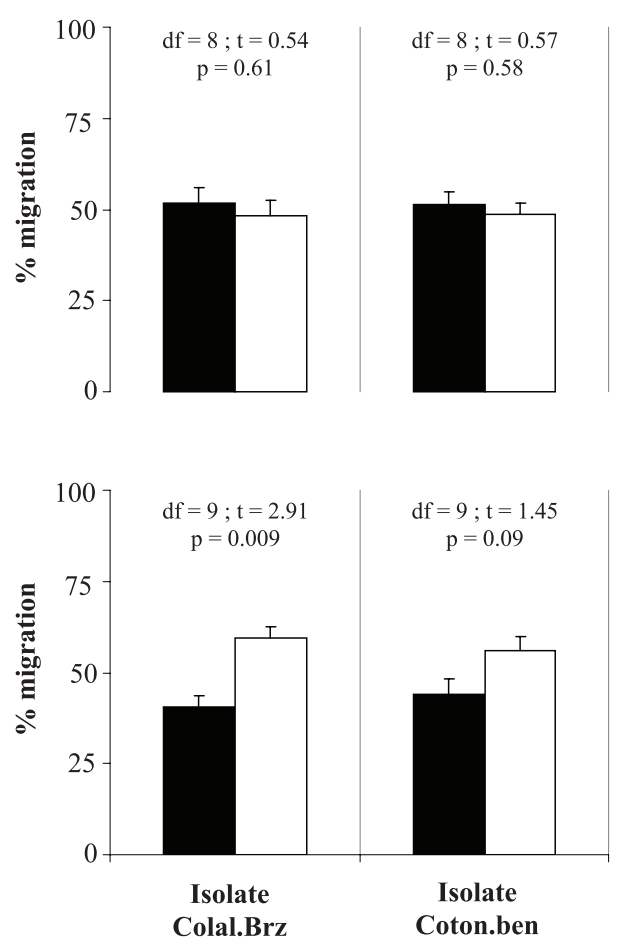

Figure 4 Migration of cassava green mite, Mononychellus tanajoa, in a two-choice unit between a clean cassava leaf disc (white bars) and a disc either treated (black bars) with a Beninese (Coton.ben) or a Brazilian (Colal.brz) isolate of its fungal pathogen Neozygites tanajoae. Top: treatment disc with mummified mite infected by $N$. tanajoae; bottom: treatment disc with spores. 


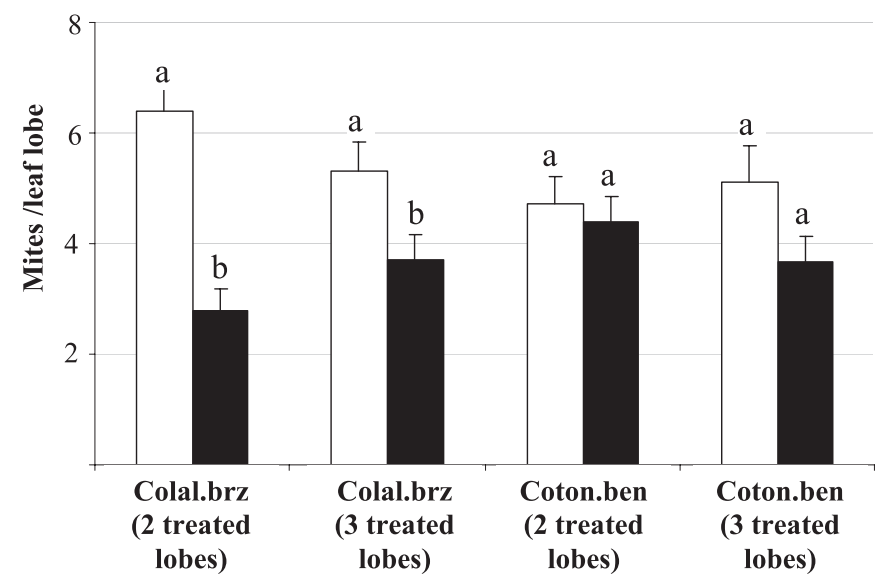

Figure 5 Migration of the cassava green mite Mononychellus tanajoa between clean cassava leaf lobes (white bars) and cassava leaf lobes either treated (black bar) with a Beninese (Coton.ben) or a Brazilian (Colal.brz) isolate of its fungal pathogen Neozygites tanajoae.

went to the side of the two-choice unit with spores: $40.7 \pm 3.1 \%$ for Colal.brz and $44.2 \pm 3.9 \%$ for Coton.ben. In contrast, when the pathogen was inside the mite (mummified CGM infected by the pathogen), CGM did not avoid the mummies. Nearly half of the migrating mites went to the side of the two-choice unit with mummies [51.8 $\pm 4.2 \%$ for Colal.brz $(P=0.61)$ and $51.5 \pm 3.2 \%$ for Coton.ben $(P=0.58)$ ].

Avoidance of $N$. tanajoae spores was also evident in the trial using cassava leaves, particularly for the Colal.brz isolate (Fig. 5). Although fewer migrating mites were generally observed on the lobes with than on those without spores for Coton.ben, the difference was not significant. Pathogen distribution among leaf lobes appears to influence the importance of avoidance depending on the isolate. Avoidance was more pronounced when spores were displayed on two lobes than on three lobes for Colal.brz, whereas it was the opposite for the Coton.ben isolate.

\section{DISCUSSION}

These experiments demonstrate that infochemicals influence interactions between CGM and its pathogen $N$. tanajoae. Cassava GLV inhibited spore production of N. tanajoae, whereas cassava HIPV produced following herbivory by CGM promoted spore production of $N$. tanajoae. Cues from $N$. tanajoae were found to influence mite behaviour.

Evidence of GLV influence on $N$. tanajoae results from observations on the Colal.brz isolate in the closed-dish experiment, where production of conidia was consistently higher in clean air than in an environment with damaged (excised) leaf discs. Evidence of an impact of HIPV influence is based on three arguments: (1) the highest production of conidia in the infested-disc treatment despite the inhibition effect of GLV in the closed-dish experiment; (2) the significantly higher production of conidia and capilliconidia for Coton.ben and Colal.brz isolates, respectively, in the HIPV compared with clean air treatment of the airflow experiment; and (3) the significantly higher production of conidia in an environment with MeSA than in an environment without MeSA. The increase in spore production in an environment with HIPV suggests a defense strategy of the cassava plant as it would promote host-to-host transmission on the leaves. Surprisingly, improved conidia production due to HIPV does not always result in improved infection (Baverstock et al., 2005). Inhibition of spore production by high production of GLV may reduce the action of HIPV as observed in the closed-dish experiment with excised leaves.
However, temporary GLV-inhibition of spore germination was observed for another arthropod pathogen as a strategy for awaiting the host (Brown et al., 1995) and inhibition of growth was also observed for M. anisopliae and T. cylindrosporum in the laboratory, but not under field conditions (Klingen et al., 2002). Cassava volatiles, especially HIPV, may thus well help indirectly to protect the cassava plant from CGM attack.

The influence of cues from the acaropathogen is evident in the avoidance behaviour of CGM towards spores of $N$. tanajoae in both the two-choice and the leaf-lobe experiments, and the indifferent behaviour of $M$. tanajoa towards the acaropathogen when inside the mite, a result obtained for both isolates. It is realistic that avoidance takes place on infested cassava leaves given the spatial distribution of the acaropathogen. Spores are displayed within $8 \mathrm{~mm}$ around the sporulating mites hither and thither on the leaf surface, allowing pathogen-free spaces for avoidance. It is not clear why $N$. tanajoae produces cues that betray its presence. Production of cues may be the consequence of unavoidable physiological processes. However, the inability of the host mite to recognize the acaropathogen when inside the host would profit the pathogen. Infected mites mummify on the leaf and wait for favorable conditions to produce spores. It is thus profitable for the mummies to stay unnoticed in mite patches until they sporulate. The non-attraction of mummified infected mites may be the result of the confinement of the pathogen cues in the mite body and may have evolved as a strategy of the pathogen to increase its transmissibility. In this case it is expected from infected mites as long as they are still alive to transport the fungus to dense mite patches. We hypothesize that infected mites act as a Trojan horse for $N$. tanajoa to infect $M$. tanajoa populations.

As seen throughout these studies, $N$. tanajoae's performance depends on its management of the chemical information present in the tritrophic system (Hountondji, 2008). In nature, chemical signaling is subject to variability due to the environment sensu lato and its impact on the various levels of the system (plant, herbivore, and pathogen). This could explain variability observed in the results of these studies, particularly in the responses of $N$. tanajoae isolates. The isolates of $N$. tanajoae demonstrated specificity in the treatment of the chemical information and infochemical dosage may play an important role in this as exemplified by the closed-dish vs. airflow HIPV experiments. Variation in emission of volatiles is found in many plant-herbivore systems (Dicke, 1999, 2000; Turlings et al., 1990); dosage might 
thus interfere with the strength of interaction. On a different scale, our experiments on sporulation were conducted under supposedly optimal conditions whereas in the field, the pathogen is mostly subject to suboptimal conditions. Further studies should consider testing the effect of HIPV and GLV on sporulation of $N$. tanajoae under suboptimal conditions and the effect of dosage, density of host and pathogen in the different interaction studies. Further experiments should also be conducted to test the Trojan horse behaviour, as this may have profound consequences for evaluation of the transmission rate of arthropod pathogens.

\section{Acknowledgements}

The authors thank the Center for Technical and Rural Cooperation, the Danish International Development Agency, the Internationa Fund for Agricultural Development, the International Institute of Tropical agriculture, and the University of Amsterdam for support, and H. Dossounon, R. Bocco, and K. Yènou for help.

\section{REFERENCES}

Baverstock J, Elliot SL, Alderson PG, \& Pell JK (2005) Response of the entomopathogenic fungus Pandora neoaphidis to aphid-induced plant volatiles. J Invertebr Pathol 89:157-164

Brown GC, Prochaska GL, Hildebrand DF et al. (1995) Green leaf volatiles inhibit conidial germination of the entomopathogen Pandora neoaphidis (Entomopthorales: Entomophthoraceae). Environ. Entomol. 24: 1637-1643.

Dara, S.K., Lomer, C.J., Hountondji, F.C.C. \& Yaninek, J.S. (2001) Seasonal incidence of two fungal pathogens Neozygites floridana (Zygomycotina: Zygomycetes) and Hirsutella thompsoni (Deuteromycotina: Hyphomycetes), in mite populations on cassava in Benin, 503-507 pp. In Akoroda M.O. and Ngeve J.M. (eds.), Root crops in the 21st century. Proceedings of the 7th Triennial Symposium of the International Society for Tropical Root CropsAfrica Branch (ISTRC-AB), October 11-17, 1998, Cotonou, Benin.

Delalibera Jr I \& Hajek AE (2004) Pathogenicity and specificity of Neozygites tanajoae and Neozygites floridana (Zygomycetes: Entomophthorales) isolates pathogenic to the cassava green mite. Biol. Contr. 30: 608-616.

Delalibera Jr I, Hajek AE \& Humber RA (2004) Neozygites tanajoae sp. nov., a pathogen of the cassava green mite. Mycologia 96: 1002-1009.

Delalibera Jr I, Sosa-Gomes DR, De Moraes GJ et al. (1992) Infection of Mononychellus tanajoa (Acari: Tetranychidae) by the fungus Neozygites sp. (Entomophthorales) in Northeastern Brazil. Florida Entomologist 75: 145-147.

Dicke M (1999) Are herbivore-induced plant volatiles reliable indicators of herbivore identity to foraging carnivorous arthropods? Entomol. Exp. Appl. 91: 131-142.

Dicke M (2000) Chemical ecology of host-plant selection by herbivorous arthropods: a multitrophic perspective. Biochem. Syst. Ecol. 28: 601-617.

Dicke M \& Sabelis MW (1988) How plants obtain predatory mites as bodyguards. Neth. J. Zool. 38: 148-165.

Dicke M, Sabelis MW, Takabayashi J et al. (1990) Plant strategies of manipulating predator-prey interactions through allelochemicals: prospects for application in pest control. J. Chem. Ecol. 16: 3091 3118.

Gnanvossou D, Hanna R, Dicke M \& Yaninek JS (2001) Attraction of the predatory mites Typhlodromalus manihoti and Typhlodromalus aripo to cassava plants infested by cassava green mite. Entomol. Exp. Appl. 101: 291-298.
Grostal P \& Dicke M (2000) Recognising one's enemies: a functional approach to risk assessment by prey. Behav. Ecol. Sociobiol. 47: 258-264.

Hountondji FCC, Sabelis MW, Hanna R \& Janssen A (2005) Herbivore-induced plant volatiles trigger sporulation in entomopathogenic fungi: The case of Neozygites tanajoae infecting the cassava green mite. J. Chem. Ecol. 31: 1003-1021.

Hountondji FCC, Hanna R \& Sabelis MW (2006) Does methyl salicylate, a component of herbivore-induced plant odour, promote sporulation of the mite-pathogenic fungus Neozygites tanajoae? Exp. Appl. Acarol. 39: 63-74.

Hountondji FCC (2008) Lessons from interactions within the cassava green mite fungal pathogen Neozygites tanajoae system and prospects for microbial control using Entomophthorales. Exp. Appl. Acarol. 46: 195-210.

James DG (2005) Further field evaluation of synthetic herbivoreinduced plant volatiles as attractants for beneficial insects. J. Chem. Ecol. 31: 481-495.

Janssen A, Bruin J, Jacobs G, Schraag R \& Sabelis MW (1997) Predators use volatiles to avoid prey patches with conspecifics. J. Anim. Ecol. 66: 223-232.

Janssen A, Pallini A, Venzonc M \& Sabelis MW (1998) Behaviour and indirect interactions in food webs of plant-inhabiting arthropods: Review. Exp. Appl. Acarol. 22: 497-521.

Klingen I, Hajek A, Meadow R \& Renwick JAA (2002) Effect of brassicaceous plants on the survival and infectivity of insect pathogenic fungi. BioControl 47: 411-425.

Magalhães S, Janssen A, Hanna R \& Sabelis MW (2002) Flexible antipredator behaviour in herbivorous mites through vertical migration in a plant. Oecologia 132: 143-149.

Nakashima Y, Birkett MA, Pye BJ, Pickett JA \& Powell W (2004) The role of semiochemicals in the avoidance of the seven-spot ladybird, Coccinella septempunctata, by the aphid parasitoid, Aphidius ervi. J. Chem. Ecol. 30: 1103-1116.

Oduor GI, De Moraes GJ, Yaninek JS \& van der Geest LPS (1995) Effect of temperature, humidity and photoperiod on mortality of Mononychellus tanajoa (Acari: Tetranychidae) infected by Neozygites cf. floridana (Zygomycetes: Entomophthorales). Exp. Appl. Acarol. 19: 571-579.

Oduor GI, De Moraes GJ, van der Geest LPS \& Yaninek JS (1996) Production and germination of primary conidia of Neozygites floridana (Zygomycetes: Entomophthorales) under constant temperature, humidity, and light conditions. J. Invert. Path. 68: 213-222.

Oi DH \& Pereira RM (1993) Ant behaviour and microbial pathogens (Hymenoptera: Formicidae). Fla. Entomol. 76: 63-74.

Outreman Y, Ralec A, Plantegenest M, Chaubet B \& Pierre JS (2001) Superparasitism limitation in an aphid parasitoid: cornicle secretion avoidance and host discrimination ability. J. Insect Physiol. 47: 339-348

Pallini A, Janssen A \& Sabelis MW (1999) Spider mites avoid plant with predators. Exp. Appl. Acarol. 23: 803-815.

Price PW, Bouton CE, Gross P et al. (1980) Interactions among three trophic levels: Influence of plant on interactions between insect herbivores and natural enemies. Annu. Rev. Ecol. Syst. 11: 41-65.

Turlings TCJ, Tumlinson JH \& Lewis WJ (1990) Exploitation of herbivore-induced plant odors by host-seeking parasitic wasps. Science 250: 1251-1253.

Yaninek JS \& Herren HR (1988) Introduction and spread of the cassava green mite, Mononychellus tanajoa (Bondar) (Acari: Tetranychidae), an exotic pest in Africa and the search for appropriate control methods: a review. Bull. Entomol. Res. 78: 1-13.

Yaninek JS, Saizonou S, Onzo A et al. (1996) Seasonal and habitat variability in the fungal pathogens: Neozygites cf. floridana and Hirsutella thompsonii, associated with cassava mites in Benin. Biocontr. Sci. Techn. 6: 23-33. 
